\title{
Efektivitas Ekstrak Hipofisa Sapi terhadap Produktivitas Ayam Petelur (Gallus gallus) Afkir Strain Hisex Brown
}

\section{Effectiveness Of Bovine Pituitary Extract Injection on Productivity Layer (Gallus gallus) at Final Period Of Hisex Brown Strain}

\author{
A. Nubatonis ${ }^{1}$, W. M. Nalley ${ }^{2}$, T. M. Hine ${ }^{2}$ \\ ${ }^{1}$ PPs Program Studi Ilmu Peternakan Universitas Nusa Cendana, \\ ${ }^{2}$ Fakultas Peternakan Universitas Nusa Cendana, Bidang Ilmu Reproduksi Ternak \\ e-mail : nubatonisalfred@gmail.com
}

\begin{abstract}
The study was conducted to examine the effectiveness of bovine pituitary extract (BPE) on the productivity of hisex brown layer strain at final period. We used of 60 hisex brown layer strain aged 88 week old with body weight $2.01 \pm 8.30 \mathrm{~kg}$. The hens were randomized with a complete randomized design into five groups, each group injected with $0,7.5,15,22.5$ or $30 \mathrm{mg} \mathrm{BPE} / \mathrm{kg}$ body weight. Injection was done intramuscularly on the chest muscle with a frequency of once a week. Each treatment was repeated four times, with three hens on each replication. Data were analyzed by Analysis of Variance and Duncan test. The results showed that BPE injection did not significantly increase egg production, feed conversion, egg index, egg white index, egg yolk index, haugh unit, and shell thickness ( $p>0.05)$, decreased egg weight and feed consumption $(p<0.05)$, and increased the egg yolk index $(\mathrm{p}<0.05)$. It was concluded that BPE injection was not effective to improve productivity of hisex brown layer strain at final period.
\end{abstract}

Key words: bovine pituitary extract, hisex brown layer strain, productivity, final period.

\begin{abstract}
ABSTRAK
Penelitian ini bertujuan untuk menguji efektivitas ekstrak hipofisa sapi (EHS) terhadap produktivitas ayam petelur tipe hisex brown periode afkir. Penelitian ini menggunakan 60 ekor ayam petelur tipe hisex brown yang berumur 88 minggu dengan berat badan $2,01 \pm 8,30 \mathrm{~kg}$. Ayam-ayam tersebut diacak dengan rancangan acak lengkap ke dalam lima grup dan diinjeksi EHS dengan konsentrasi: $0 ; 7,5 ; 15 ; 22,5$ atau $30 \mathrm{mg} / \mathrm{kg}$ bobot badan. Injeksi dilakukan secara intramuskuler pada otot dada dengan frekuensi satu kali per minggu. Masing-masing perlakuan diulang empat kali, dengan tiga ekor ayam pada setiap ulangan. Data penelitian dianalisis dengan sidik ragam dan dilanjutkan dengan uji Duncan. Hasil penelitian menunjukkan bahwa injeksi EHS tidak mampu meningkatkan produksi telur, konversi pakan, indeks telur, indeks putih telur, indeks kuning telur, haugh unit, dan tebal kerabang ( $>>0,05)$, menurunkan bobot telur dan konsumsi pakan $(\mathrm{p}<0,05)$, dan meningkatkan indeks warna kuning telur $(\mathrm{p}<0,05)$. Disimpulkan bahwa injeksi EHS tidak efektif untuk meningkatkan produktivitas ayam petelur tipe hisex brown periode afkir.
\end{abstract}

Kata kunci : ekstrak hipofisa sapi, hisex brown, produktivitas, periode afkir

\section{PENDAHULUAN}

Populasi ayam petelur dan produksi telur dari tahun 2014-2015 meningkat sebesar 3,24 \% (Direktorat Jenderal Peternakan dan Kesehatan Hewan, 2015). Peningkatan ini diikuti dengan peningkatan jumlah ayam yang diafkir. Pemanfaatan ayam petelur afkir masih sangat kurang, populasi ayam petelur pada tahun 2000 mencapai 69.033.000 ekor sehingga diperkirakaan pada tahun 2001 di Indonesia terdapat 70 juta ekor ayam afkir di Indonesia bahkan di duniamencapai 2,6 milyar ekor ayam petelur afkir yang dihasilkan oleh usaha peternakan ayam petelur (Singh and Gandhi, 2001; Ditjen Peternakan dan Kesehatan Hewan, 2015).

Populasi meningkat diikuti dengan peningkatan konsumsi telur ayam, pada tahun 2015 konsumsi telur $5,55 \mathrm{~kg} / \mathrm{kapita}$ dan pada tahun 2016 meningkat menjadi 5,73 $\mathrm{kg} / \mathrm{kapita}$ dan di prediksi pada tahun 2020 akan mencapai $6,43 \mathrm{~kg} / \mathrm{kapita}$ dengan rata- 
rata pertumbuhan sebesar $2,98 \%$ per tahun (Pusdatin, 2016). Data di atas menunjukkan bahwa konsumsi telur di Indonesia terus meningkat seiring dengan peningkatan jumlah penduduk dan kesadaran akan pemenuhan gizi, dimana jumlah penduduk pada tahun 2016 berjumlah 261,1 juta jiwa (BPS, 2016 ; Delgado et al., 1999).

Produksi telur akan terjadi penurunan secara bertahap hingga ayam berumur 82 minggu dengan rata-rata produksi $50 \%$ (Wahyu, 1997), Penurunan produksi telur ini erat kaitanya dengan fungsi fisiologis organorgan reproduksi (Latifa dan Sarmanu, 2008). Oleh karena itu, perlu dilakukan kajian terhadap produksi ayam petelur afkir, guna meningkatkan produksi dan menambah nilai ekonominya.

Produktivitas ayam petelur afkir dapat ditingkatkan dengan pemberian hormon pregnant mare serum gonadotropin (PMSG), (Malik dan Gunawan, 2008; Budiasa dan Bebas, 2008; Latifa dan Sarmanu, 2008). Hormon PMSG mengandung Folicel Stimulating Hormon (FSH) dan Luteinizing Hormon (LH) yang dapat memelihara saluran reproduksi agar dapat bersiklus normal (Hafez dan Hafez, 2000). Selanjutnya Hafizuddin et al. (2010) membuktikan bahwa ekstrak hipofisa dan PMSG mempunyai efektivitas yang sama dalam menginduksi superovulasi pada mencit. Penggunaan PMSG untuk meningkatkan produktivitas ayam pada usia afkir dibatasi oleh biaya dan sulitnya memperoleh hormon tersebut di pasar lokal. Solusi alternatif adalah dengan cara memberikan ekstrak hipofisa yang merupakan limbah rumah potong hewan.

Kelenjar hipofisa merupakan organ yang kecil ukurannya jika dibandingkan dengan ukuran tubuh, namun mempunyai pengaruh sangat vital dalam tubuh hewan (Hafez dan Hafez, 2000). Beberapa hasil penelitian membuktikan keberadaan FSH dalam ekstrak hipofisa, diantaranya Isnaini et al. (1999) melaporkan bahwa sumber utama hormon FSH terdapat pada hipofisa anterior, selanjutnya telah dibuktikan akan kemampuan ekstrak hipofisa menggantikan fungsi FSH (Isnaini dan Suyadi, 2004;
Hafizuddin et al., 2010; Siregar et al., 2013), sebagai hormon yang berperan penting dalam pembentukan folikel dan ovulasi yang secara langsung berfungsi dalam proses pembentukan telur.

Berdasarkan uraian diatas, maka telah dilakukan penelitian tentang efektivitas penyuntikan ekstrak hipofisa terhadap produktivitas ayam petelur afkir.

Penelitian ini bertujuan untuk menguji efektivitas EHS terhadap produktivitas ayam petelur afkir strain hisex brown. Hasil penelitian ini diharapkan dapat memberikan informasi penggunaan EHS dan berguna bagi penelitian selanjutnya, tentang EHS pada ayam petelur afkir strain hisex brown.

\section{MATERI DAN METODE}

Penelitian dilaksanakan pada bulan Mei hingga Oktober 2016 dan materi yang digunakan 60 ekor ayam petelur(Gallus gallus) strain hisex brown berumur 88 bulan yang mengalami penurunan produksi telur sekitar 50-55 \% yang ada pada peternakan ayam petelur PT. Waris-Oesao, Kabupaten Kupang. Seluruh ayam petelur dibagi dalam 5 kelompok perlakuan dengan 4 ulangan dan disetiap ulangan terdapat 3 unit ternak, dengan pola perlakuan sebagai berikut : $\mathrm{P} 0=$ Penyuntikan $\mathrm{NaCl}$ Fisiologis, $\mathrm{P} 1=$ Penyuntikan Ekstrak Hipofisa 7,5 $\mathrm{mg} / \mathrm{Kg}$ BB; $\mathrm{P} 2$ = Penyuntikan Ekstrak Hipofisa $15 \mathrm{mg} / \mathrm{Kg} \mathrm{BB}, \mathrm{P} 3=$ Penyuntikan Ekstrak Hipofisa 22,5 mg/Kg BB, P4=Penyuntikan Ekstrak Hipofisa 30mg/Kg BB. Penyuntikan dilakukan secara intramuskular pada otot atau paha, setiap seminggu sekali selama 12 minggu.

\section{Prosedur Ekstrak Hipofisa}

Ekstrak hipofisa dibuat berdasarkan metode yang diterapkan Nalley (1993). Hipofisa sapi yang dioleksi dari RPH segera dibawa ke laboratoriumdan dibersihkan dan dicuci menggunakan $\mathrm{NaCl}$ Fisiologis. Selanjutnya diawetkan secara kering menggunakan aceton PA(pro analisis) pada suhu kamar $\left(28-30^{\circ} \mathrm{C}\right)$. Setelah itu hipofisa 
yang telah diawetkan, dihaluskan menjadi tepung, kemudian ditimbang sesuai perlakuan dan dilarutkan dengan $\mathrm{NaCl}$ Fisiogis hingga larut dan mengukur jumlah pelarut disetiap perlakuan. Larutan yang di peroleh disentrifugasi dengan kecepatan 3000 rpm selama 15 menit, kemudian supernatan diambil. Supernatan hasil senrtifugasi merupakan ekstrak hipofisa yang siap digunakan.

\section{Analisis Data}

Pengamatan dan produksi telur, bobot telur, konsumsi pakan dan konversi pakan pada ayam petelur dilakukan selama waktu penelitian. Data yang terkumpul dianalisis secara statistik menggunakan Analisis of Varians.

\section{HASIL DAN PEMBAHASAN}

\section{Pengaruh penyuntikan EHS terhadap produksi telur}

Rataan produksi telur ayam petelur tertinggi dihasilkan pada perlakuan P2 yakni $66,66 \% \pm 11,78$ dan terendah dihasilkan oleh perlakuan P4 yakni 43,75\% \pm 20,83 (Tabel 1).

Hasil analisis statistik menunjukkan bahwa perlakuan berpengaruh nyata $(\mathrm{P}<0,05)$ terhadap produksi telur. Hasil penelitian ini menunjukkan bahwa penggunaan ekstrak hipofisa sapi (EHS) sampai dengan 15 $\mathrm{mg} / \mathrm{Kg} / \mathrm{bb}$ dapat meningkatkan produksi telurdan pada dosis yang lebih tinggi yaitu 22,5 hingga $30 \mathrm{mg} / \mathrm{Kg} / \mathrm{bb}$ menurunkan produksi telur. Penggunaan EHS sampai dengan dosis $15 \mathrm{mg} / \mathrm{kg} / \mathrm{bb}$ meningkatkan produksi telur, diduga karena kandungan bahan aktif yang terkadung dalam dosis tersebut cukup optimal sehingga mempengaruhi aktivitas hormon FSH dan LH dalam meransang pertumbuhan foliker primer, sehingga dapat meningkatkkan produksi telur.

Peningkatan produksi telur pada perlakuan P2 bila dibandingkan dengan perlakuan P0 maka peningkatan produksi telur ayam afkir yaitu sebesar 14,58 \%. Peningkatan produksi telur ini diduga karena bahan aktif yang terkandung dalam EHS dengan dosis penyuntikan $15 \mathrm{mg} / \mathrm{Kg} / \mathrm{bb}$ terutama hormon FSH dan LH cukup optimal dalam merangsang pertumbuhan folikel dengan masa paruh yang cukup singkat sehingga banyak folikel yang berkembang dan diovulasi sehingga produksi telur meningkat. Semakin banyak jumlah folikel yangberkembang maka semakin banyak pula hormon estrogen yang dihasilkan dan selanjutnya berperan dalam proses pembentukan telur untuk diovulasikan. Arum et al. (2013) melaporkan bahwa pemberian ekstrak hipofisa sapi dapat meningkatkan respon superovulasi sapi aceh yang ditandai dengan peningkatan jumlah corpus luteum dan embrio.

Sarmanu (1993) melaporkan bahwa penyuntikan PMSG yang mengandung bahan aktif FSH dan LH sebesar 20 IU dapat meningkatkan produksi telur ayam kampung. Selanjutnya Artiningsih (1996) melaporkan bahwa penyuntikan PMSG 15 IU yang dikombinasikan dengan Medroxyprogesteron Acetate secara intravaginal pada kambing dara Peranakan Etawa efektif menyerentakkan birahi dan meningkatkan jumlah anak lahir perinduk.

Dosis optimal penggunaan EH untuk meningkatkan produksi telur ayam petelur afkir diprediksi berada diantara 15$22,5 \mathrm{mg} / \mathrm{kg} / \mathrm{bb}$, karena pada dosis yang lebih tinggi menurunkan produksi telur.

Tabel 1. Rataan produksi telur, bobot telur perlakuan

\begin{tabular}{|c|c|c|c|c|c|}
\hline \multirow{3}{*}{ Parameter } & \multicolumn{5}{|c|}{ Perlakuan } \\
\hline & P0 & P1 & P2 & P3 & P4 \\
\hline & $\mathrm{NaCl}$ Fis & EHS 7,5 & EHS 15 & EHS 22,5 & EHS 30 \\
\hline Produksi telur (\% Hen Day) & $52,08 \pm 7,97^{\mathrm{ab}}$ & $54,16 \pm 14,43^{a b}$ & $66,66 \pm 11,78^{b}$ & $50,00 \pm 6,80^{\mathrm{ab}}$ & $43,75 \pm 20,83^{\mathrm{a}}$ \\
\hline Bobot telur (g/butir/ekor) & $70,00 \pm 1,41^{\mathrm{c}}$ & $66,25 \pm 3,50^{\mathbf{b}}$ & $62,75 \pm 2,21^{\mathrm{a}}$ & $65,00 \pm 1,41^{\text {ab }}$ & $64,00 \pm 1,41^{\mathrm{ab}}$ \\
\hline
\end{tabular}


Penyuntikan EHS dengan dosis tinggi yakni $22,5-30 \mathrm{mg} / \mathrm{Kg}$ bb dapat menurunkan produksi telur. Penurunan produksi telur ini diduga karena penyuntikan EHS peningkatan produksiestrogen dan progesteron yang berlebihan oleh folikel. Dimana konsentrasi EH yang tinggi menyebabkan peningkatankadar estrogen dan progesteron yang lebih tinggi, kondisi ini mengakibatkan umpanbalik negatif terhadap sekresi hormon LH (rendahnya kadar LH) sehingga ovulasi menjadi terhambat yang berdampak pada penurunan produksi telur (Hafez dan Hafez, 2000).

Dosis gonadotropin yang berlebihan dapat menurunkan jumlah anak per kelahiran. Newton dan Betts (1968) membuktikan bahwa pemberian PMSG dengan dosis 2000 IU ternyata menurunkan jumlah anak per kelahiran menjadi 2,44 ekor sedangkan pada dosis optimal yakni 1500 IU jumlah anak per kelahiran ialah 2,81 ekor. Induksi dengan gonadotropin yang berlebihan menyebabkan peningkatan folikel sistik dan ketidakseimbangan hormonal yang diikuti dengan tingginya tingkat kematian embrio (Maerthens dan Luzi, 1995).

\section{Pengaruh penyuntikan EHS terhadap bobot telur}

Rataan bobot telur tertinggi ayam petelur afkir dihasilkan oleh perlakuan P0 yaitu 70 gram/butir sedangkan bobot yang terendah pada perlakuan P2 yaitu 62,75 gram/butir. Secara umum bobot telur ayam yang mendapat perlakuan kontrol lebih tinggi dibandingkan dengan yang mendapat perlakuan EH.

Hasil analisis statistik menunjukkan bahwa perlakuan berpengaruh nyata $(\mathrm{P}<0,05)$ terhadap produksi telur dan terdapat perbedaan bobot telur yang signifikan
$(\mathrm{P}<0,05)$ antara perlakuan $\mathrm{P} 0$ dengan $\mathrm{P} 1, \mathrm{P} 2$, P3, P4 dan antara P1 dengan P2. Hasil Penelitian ini menunjukkan bahwa penyuntikan ekstrak hipofisa memberikan umpan balik negative terhadap bobot telur. Penurunan bobot telur ini dipengaruhi oleh tingkat konsumsi, dimana penyuntikan $\mathrm{EH}$ pada semua level perlakuan dapat memacu peningkatan produksi hormon estrogen dan leptin yang di produksi oleh kelenjar adiposa yang selanjutnya menekan nafsu makan. Menurunnya konsumsi pakan pada ayam petelur afkir akan mempengaruhi proses sintesis protein dan asam amino yang terkandung dalam ransum yang dikonsumsi sehingga secara keseluruhan dapat mempengaruhi bobot telur.

\section{Pengaruh penyuntikan EHS terhadap konsumsi pakan}

Konsumsi pakan kaitan erat kaitannya dengan produksi telur. Rataan tingkat konsumsi pakanayam petelur, secara umum perlakuan kontrol lebih tinggi dibandingkan dengan perlakuan P1, P2, P3 dan P4. Konsumsi pakan tertinggi terdapat pada perlakuan P0 yaitu 89,24 gram/ekor/hari dan yang terendah pada perlakuan P3 yaitu 74,21 gram/ekor/hari (Tabel 2).

Hasil analisis statistik menunjukkan bahwa perlakuan berpengaruh nyata $(\mathrm{P}<0,05)$ terhadap konsumsi pakan. Hasil uji jarak berganda Duncan menunjukkan bahwa tingkat konsumsi pakan antara perlakuan $\mathrm{P} 0$ dengan $\mathrm{P} 1$ tidak berbeda nyata $(\mathrm{P}>0,05)$ sedangkan $\mathrm{P} 0$ dengan $\mathrm{P} 2, \mathrm{P} 3$ dan $\mathrm{P} 4$ berbeda nyata $(\mathrm{P}<0,05)$. Hasil Penelitian ini menunjukkan bahwa penggunaan ekstrak hipofisa pada semua level konsentrasi dapat menurunkan tingkat konsumsi pakan ayam petelur afkir.

Tabel 2. Rataan tingkat konsumsi dan konversi pakan perlakuan

\begin{tabular}{|c|c|c|c|c|c|}
\hline \multirow{3}{*}{ Parameter } & \multicolumn{5}{|c|}{ Perlakuan } \\
\hline & $\mathrm{P} 0$ & P1 & $\mathrm{P} 2$ & $\mathrm{P} 3$ & $\mathrm{P} 4$ \\
\hline & $\mathrm{NaCl}$ Fis & EHS 7,5 & EHS 15 & EHS 22,5 & EHS 30 \\
\hline Konsumsi pakan (g/ekor/hari) & $89,24 \pm 1,83^{\mathrm{c}}$ & $87,00 \pm 4,56^{\text {bc }}$ & $77,44 \pm 11,24^{\mathrm{ab}}$ & $74,21 \pm 5,32^{\mathrm{a}}$ & $78,76 \pm 5,04^{a b}$ \\
\hline Konversi pakan & $3,41 \pm 0,99^{\mathrm{ab}}$ & $3,11 \pm 0,99^{a}$ & $2,81 \pm 1,02^{\mathrm{a}}$ & $6,51 \pm 3,30^{\mathrm{bc}}$ & $6,02 \pm 1,25^{b}$ \\
\hline
\end{tabular}

Ket: $\quad$ Superskrip berbeda pada baris yang sama menunjukan perbedaan nyata antar perlakuan $(\mathrm{P}<0,05)$ 
Tingkat konsumsi semakin menurun seiring dengan meningkatnya konsentrasi terlarut dan dosis penyuntikan EHS pada ayam petelur afkir. Hal ini disebabkan karena meningkatnya konsentarsi EHS terlarut yang selanjutnyamerangsang proses terbentuknya hormon estrogen yang lebih banyak. Diduga hormon estrogen yang tinggi di dalam tubuh ternak ayam petelur afkir akan merangsang produksi hormon leptin yang selanjutnya menekan nafsu makan. Dengan demikian dalam kondisi tingginya konsentrasi EHS di dalam tubuh ayam petelur afkir (seperti yang terjadi pada ayam yang mendapat perlakuan P1, P2, P3, dan P4) maka konsentrasi FSH dan LH juga tinggi yang selanjutnya mengadakan feed back positif terhadap produksi hormon estrogen dari folikel ovarium. Tingginya kadar hormon estrogen merangsang produksi dan sisntesis leptin dari jaringan adipose sehingga kadar leptin di dalam darah mengalami peningkatan. Kadar leptin di dalam darah yang tinggi menyebabkan penekanan nafsu makan sehingga konsumsi pakan semakin rendah. Sebaliknya dalam kondisi tanpa kadar EHS (seperti pada perlakuan P0) akan menyebabkan ayam perlakuan mengalami hipoestrogen dan hipoleptin dan mengakibatkan sinyal kenyang ditekan sehingga konsumsi ransum meningkat (Wahyuni, 2015). Hasil penelitian ini menunjukkan bahwa penyuntikan EHS dapat memacu dan meningkatkan hormon estrogen yang terbentuk dan meningkatkan produksi hormon leptin sehingga menekan tingkat konsumsi pakan pada ternak ayam petelur afkir (tingkat konsumsi pakan rendah).

Siahaan et al. (2013) menyatakan bahwa menurunnya konsumsi ransum menyebabkan berkurangnya nutrisi dalam tubuh dan akhirnya menurunkan produksi telur. Selanjutnya Rusli (2011) menyatakan jumlah zat makanan yang terkandung didalam ransum sangat diperlukan dalam proses pembentukan telur.

Limanan (2013) melaporkan bahwa kadar hormon leptin dalam sirkulasi darah dipengaruhi oleh jumlah produksi leptin dari jaringan adiposa dengan sistem kerja pada central nervous sistem (CNS) terutama hypotalamus, dengan efek menekan asupan makanan dan meningkatkan energi yang dikeluarkan.

Meutia (2005) dalam laporannya menjelaskan bahwa Leptin merupakan mata rantai yang sangat penting antara jaringan lemak dengan hypothalamus sebagai pusat pengatur homeostatis energi. Disamping itu juga leptin juga berperan mengaktifkan reseptor-reseptornya dan aktivasi dari $\mathrm{Ob}-\mathrm{Rb}$ (long leptin sreceptor isoform) akan mengaktifkan JAK/STAT (Janus Kinase Signal Tranducer and Activator of Transscription) serta mempengaruhi ekspresi dari beberapa neuropeptida yang berasal dari hypothalamus. Selanjutnya dijelaskan bahwa peningkatan kadar hormon leptin menyebabkan stimulasi hormon neuron yang menghasilkan Proopiomelanocortin (POMC) sebagai peptida anoreksigenik yang berfungsi menekan nafsu makan.

Hasil penelitian Allama (2013) melaporkan bahwa imbangan protein dan energi sangat berpengaruh terhadap jumlah konsumsi pakan, karena energi yang terkandung dalam pakan merupakan salah satu faktor pembatas konsumsi.Secara umum, konsumsi pakan ayam petelur afkir pada penelitian ini tergolong rendah.

Suhu lingkungan yang tinggiakan menyebabkan penurunanjumlah konsumsi pakanyangbervariasi, tergantung dari strain ayam, lamanya cekaman panas, tingkat produksi, berat telur, dan kandungan energi metabolis dari pakan yang diberikan (Gunawan dan Sihombing, 2004). Hasil penelitian ini menunjukkan tingkat konsumsi pakan berkisar antara 74-89 g/ekor/hari dengan suhu lingkungan kandang berkisar 28-32 ${ }^{\circ} \mathrm{C}$. Kondisi ini berada pada kisaran yang di laporkan oleh Balnave dan Abdoellah (1990) dimana konsumsi pakan 75-94 g/ekor/hari pada suhu $25-32^{\circ} \mathrm{C}$. Selanjutnya dijelaskan bahwa penurunan konsumsi pakan juga dipengaruhi oleh meningkatnya konsumsi airminum yang digunakan untuk mempertahankan suhutubuh terhadap suhu lingkungan yang bertambah panas. 
North dan Bell (1990), menyatakan bahwa faktor yang mempengaruhi konsumsi pakan harian pada unggas yaitu kandungan energi pakan, suhu lingkungan,strain, berat tubuh, bobot telur harian, pertumbuhan bulu,derajat stress dan aktivitas ternak. Selanjutnya dijelaskan bahwa kenaikan suhu lingkungan akanmenurunkan konsumsi pakan, menurunkan produksi telur, ukuran telur dan kualitas kerabang telur.

\section{Pengaruh penyuntikan EHS terhadap konversi pakan}

Konversi ransum erat kaitannya dengan konsumsi ransum dan produksi telur, semakin kecil nilai konversi pakan maka semakin efisien produksi ternak. Rataan nilai konversi pakan ayam petelur afkir terendah pada perlakuan P2 yaitu 2,81 dan tertinggi pada perlakuan P4 yaitu 22,41 (Tabel 2).

Hasil analisis statistik menunjukkan bahwa perlakuan berpengaruh tidak nyata $(\mathrm{P}>0,05)$ terhadap konversi pakan. Hal ini berarti bahwa penyuntikan ekstrak hipofisa memberikan efek yang kurang baik pada ayam petelur afkir dalam mengkonversi pakan, dimana produksi telur yang dihasilkan tidak seimbang dengan jumlah pakan yang di konsumsi. Nilai konversi pakan ayam petelur afkir selama penelitian secara umum lebih besar dari yang dilaporkan Siregar (2003), dimana nilai konversi ransum ayam petelur yang diberi ransum bentuk mash dengan kandungan protein kasar 18\%, 2,72.

Tingginya nilai konversi pakan di duga karena penyuntikan EH dengan konsentrasi tinggi dapat memberikan umpan balik positif terhadap produksi hormon estrogen di ovarium dan ayam petelur strain hisex brown yang digunakan sudah afkir. Kadar hormon estrogen yang tinggi dapat merangsang produksi dan sistesis leptin dari jaringan adipose sehingga kadar leptin di dalam darah mengalami peningkatan dan menyebabkan konsumsi pakan rendah.

Konsumsi pakan yang rendah akan mempengaruhi produksi telur yang dihasilkan oleh ayam petelur. Puspita (2008) menjelaskan bahwa konversi ransum erat kaitannya dengan konsumsi pakan dan produksi telur,dimana semakin rendah nilai konversi ransum yang diperoleh, maka semakin efisien ternak karena erat kaitannya dengan biaya produksi. Selanjutnya Berri et al. (2005) menyatakan bahwa konversi pakan ternak ayam tergantung pada kecepatan pertumbuhan, konsumsi ransum, besar ukuran tubuh dan kesehatan ayam.

Hasil Penelitian Makund (2006) melaporkan bahwa, pemberian pakan pada ayam umur 9-19 minggu dengan kandungan energi $2700 \mathrm{Kkal} / \mathrm{kg}$ konversipakannya ialah 3,43 sedangkan pada kandungan energi 2900 $\mathrm{Kkal} / \mathrm{kg}$ konversi pakan yaitu 3,34. Nilai konversi pakan yang efisien pada penelitian ini terdapat pada perlakuan P2 yaitu 2,81, nilai ini menjelaskan bahwa untuk menghasilkan $1 \mathrm{Kg}$ telur dibutuhkan pakan sebanyak $2,81 \mathrm{Kg}$.

\section{KESIMPULAN}

Penyuntikkan EHS tidak mampu meningkatkan produksi telur, indeks putih telur, indeks kuning telur, haugh unit dan ketebalan kerabang; sebaliknya menyebabkan peningkatan indeks warna kuning telur, konversi pakan, serta menurunkan konsumsi pakan, bobot telur ayam petelur afkir strain hisex brown.

\section{DAFTAR PUSTAKA}

Allama, H., O. Sjofjan, E. Widodo dan H. S. Prayogi. 2012. Pengaruh penggunaan tepung ulat kandang (Alphitobius diaperinus) dalam pakan terhadap penampilan produksi ayam pedaging. Jurnal Ilmu-Ilmu Peternakan. 22(3):1-8.

Arum, W. P., T. N. Siregar, dan J. Melia. 2013. Efek pemberian ekstrak hipofisa sapi terhadap respons superovulasi sapi aceh. Jurnal Medika Veterinaria, 7(2):71-74

[BPS] 2016. Statistik Indonesia 2016. Badan Pusat Statistik Indonesia.

Balnave, D. and T. Abdoellah. 1990. Influence of feeding concentrate on 
layer hens on different temperatures. Australian Journal of Agricultural Research. 41: 549-555.

Berri, C., M. Debut, V. Santé-Lhoutellier, C. Arnould, B. Boutten, N. Sellier, and E. Le Bihan-Duval. 2005. Variations in chicken breast meat quality: implications of struggle and muscle glycogen content at death. British poultry science. 46 (5): 572-579.

Budiasa, M. K. dan W. Bebas. 2008. Pregnant mare serum gonadotrophin meningkatkan dan mempercepat produksi telur itik bali yang lambat bertelur. J. Veteriner. 9(1):20-24

Delgado, C., M. Rosegrant, H. Steinfeld, S. Ehui, and C. Courbois. 2001. Livestock to 2020: The next food revolution. Outlook on Agriculture. 30(1): 27-29.

Direktorat Jenderal Peternakan dan Kesehatan Hewan. 2015. Daftar Populasi, Konsumsi, dan Produksi Ternak. Jakarta.

Gunawan dan D.T.H. Sihombing. 2004. Pengaruh suhu lingkungan tinggi terhadap kondisi fisiologis dan produktivitas ayam buras. Wartazoa. 14(1) : 92-98.

Hafez, E. S. E. and B. Hafez, 2000. Reproduction in farm animals 7th ed. Wiley-Blackwell; Revised edition.

Hafizuddin, Suryani, Yusmadi, T. N. Siregar dan T. Armansyah. 2010. Respons superovulasi mencit dengan ekstrak hipofisa: suatu upaya menemukan agen superovulasi dengan biaya murah. Prosiding Seminar Nasional Peternakan Berkelanjutan. Fakultas Peternakan Universitas Padjajaran 4 November 2010:52-56.

Isnaini, N., S. Wahjuningsih dan G. Ciptadi. 1999. In vitro maturasi oosit sapi dalam tcm-199 yang disuplementasi dengan ekstrak hipofisa sapi. J. Saintek. 7(1): 75-85.

Isnaini, N. dan Suyadi. 2004. Pengaruh pemberian ekstrak hipofisa terhadap respons berahi dan respons ovari sapi perah anestrus postpartum. JIIP. 16(1):33-40.

Kadam, M. M., A. B. Mandal, A. V. Elangovan, dan S. Kaur. 2006. Response of laying Japanese quail to dietary calcium levels at two levels of energy. The Journal of Poultry Science. 43(4): 351-356.

Latifa, R. dan Sarmanu. 2008. Manipulasi reproduksi pada itik petelur afkir dengan pregnant mare serum gonadotropin. J. Penelitian Med. Eksakta. 7(1):83-91.

Limanan, D. dan A. R. Prijanti. 2013. Hantaran sinyal leptin dan obesitas: hubungannya dengan penyakit kardiovaskuler. eJKI. 1(2):149-56.

Maertens, L. and F. Luzi. 1995. Note concerning the effect of PMSG stimulation on the mortality rate at birth and the distribution of litter size in artificially inseminated doses. World Rabbit Science. 3(1):57-61.

Malik, A. dan Gunawan, A. 2008. Efek penyuntikan dosis rendah hormon gonadotropin terhadap jumlah dan besar telur itik alabio. Jurnal Ilmu Ternak. 8(1): 91-94.

Nalley, W. M. 1993. Perbandingan penggunaan ekstrak hipofisa hipotalamus bagian dorsal dan bagian ventral babi terhadap spermiasi dan daya tetas telur ikan mas (Cyprianus carpio L). Program Pasca SarjanaIPB Bogor.

Newton, J. E. and J. E. Betts. 1968. Factors affecting litter size in the Scotch Half- 
Bred ewe. J. Reprod. Fert. 17:485483.

North, M. O. and D. D. Bell. 1990. Commercial Chicken Production Manual. The $4^{\text {th }}$ Ed. Avi Publishing Company Inc.Westport, Connecticut.

[PUSDATIN] 2016. Outlook Telur 2016. Pusat Data dan Sistem Informasi Pertanian Sekretariat Jenderal Kementerian Pertanian.

Puspita. 2008. Performa ayam ras petelur periode produksi yang diberi ransum rendah kalsium dengan penambahan zeolit. Skripsi. Fakultas Peternakan, Institut Pertanian Bogor.

Rusli, K. R. 2011. Giving grounds remaining mixture bran and tofu fermentation with Monascus purpureus performance and eggs quality of layer. Tesis. Universitas Andalas. Padang.

Siahaan, N. B., E. Suprijatna, dan L. D. Mahfudz. 2013. Pengaruh penambahan tepung jahe merah (Zingiber officinale var. Rubrum) dalam ransum terhadap laju bobot badan dan produksi telur ayam kampung periode layer. Animal Agriculture Journal. 2(1) :478-488.
Singh, K. S. dan K. K. Gandhi. 2001. Capacitation and acrosome reaction in buffallo bull spermatozoa assessed by chlortetracycline and pisum sativum aglutinin fluoresence assay. Theriogenology. 55:1457-1468.

Siregar, R. T. 2003. Pengaruh perubahan waktu pemberian ransum dengan berbagai level protein terhadap performans produksi ayam ras petelur. Skripsi. Fakultas Peternakan. Institut Pertanian Bogor. Bogor.

Siregar, T. N., I. K. Siregar, T. Armansyah, Syafruddin, A. Sayuti, dan Hamdani. 2013. Kinerja reproduksi kambing lokal yang mengalami induksi manipulasi ovulasi dengan pemberian ekstrak pituitary sapi mengiringi pelaksanaan inseminasi buatan. Jurnal Veteriner. 14(2): 91-98.

Wahyu, J. 1997. Ilmu Nutrisi Unggas. Gadjah Mada University Press.Yogyakarta

Wahyuni, E. S. 2016. Efek paparan depo progestin terhadap hormon pengatur nafsu makan (leptin) dan berat badan pada tikus putih betina. Jurnal Kebidanan Indonesia: Journal of Indonesia Midwifery. 7(1): 27-37. 